\title{
The Obama administration and India
}

\author{
Christopher K. Colley* and Sumit Ganguly
}

\section{Introduction}

The dawn of the twenty-first century ushered in an era of new opportunity in Indo-US relations. While bilateral ties in the twentieth century were marred by the politics of the Cold War, as well as perceptions of American arrogance and hegemony, the first decade-and-a-half of the new century witnessed the world's two largest democracies come closer together than they had ever been. There are multiple causes for the warming of ties between Washington and New Delhi, which range from shared democratic norms, to real and perceived economic opportunities, to policies based on strategic hedging and the balance of power in the international order. This chapter specifically examines the relationship under the two Obama administrations and the first two years of the Trump administration. It argues that the overriding driver of Indo-US relations during this period was the mutual desire to hedge against the rise of China. Additionally, however, there were other factors influencing ties, chief among these economic considerations. As will be demonstrated, the focus on China and increasing trade links between the United States and India were not always sufficient to prevent domestic obstacles in both the United States and India from posing political challenges to bilateral ties. However, when examining America's relations with India during the Obama era and into the Trump regime, it is nearly impossible to decouple the broader geostrategic situation in which both states have concerns over how Beijing will wield its increasing power.

While China's rise served as a backdrop to expanding ties between Washington and New Delhi, other important (and related) events took place during Obama's eight-year presidency. Specifically, this chapter focuses on three key interrelated

* The opinions expressed in this chapter are those of the author and do not reflect the views of the National Defense College, or the United Arab Emirates government. 
aspects of bilateral ties. First, we analyse the diplomatic and political relationship between India and the United States with a focus on the major summits and political meetings at the top levels of government. This section will demonstrate that the honeymoon period of the last three years of the Bush era gave way to a more realistic bilateral relationship with the Obama administration. The second section examines economic ties and highlights the major successes, as well as significant challenges, that confronted both New Delhi and Washington. The final section focuses on the cornerstone of relations, the strategic partnership, and how this is heavily impacted by the rise of China as both a regional and global power. This segment also argues that by the end of Obama's second term, security ties between the two states were robust, but for political reasons were not at the level of a formal alliance. We conclude with a brief discussion of policy changes and continuity under the Trump regime.

\section{Background}

Throughout most of the Cold War India and the United States held different worldviews. The United States was determined to maintain its dominant position as a global hegemon and supported its allies while opposing the USSR and other communist states. India's leaders quickly saw the United States as less of a defender of post-colonial states and more of an heir to British imperialism. ${ }^{1}$ American support for India's rivals Pakistan, and later China, further divided Washington and New Delhi. Although the United States did support India in its war with China in 1962, and even supplied it with military equipment, Washington did not view New Delhi as a major ally or force in the global war against communism. In fact, America did not view India’s policy of "nonalignment" as a form of genuine neutrality. ${ }^{2}$ India's 1971 Treaty of Peace, Friendship, and Cooperation with the USSR, where Moscow and New Delhi promised to aid each other in the event of a military conflict, confirmed American suspicions. ${ }^{3}$ Washington's ties with Pakistan also posed a significant obstacle between India and the United States. Perhaps the best concrete example of the divergent interests between the United States and India during the Cold War is found in the 1971 USS Enterprise incident where the American aircraft carrier entered the Bay of Bengal as a token show of support for Pakistan during the 1971 Indo-Pakistani War. This conflict ended in the dismemberment of Pakistan and the birth of Bangladesh. India's poor economic performance throughout most of the Cold War also led Washington to not take New Delhi seriously. Added to this was India's "peaceful nuclear test" in 1974, which resulted in various legislative acts by the American Congress designed to prevent nuclear proliferation in South Asia, and the 1998 nuclear tests by both Pakistan and India, which resulted in additional American sanctions on both states. ${ }^{4}$ 
The George W. Bush administration, over the course of two terms, brought about a virtual transformation of Indo-US relations. Specifically, Bush removed one of the most trying elements in the relationship: the US attempt to induce India to abandon its nuclear weapons programme. ${ }^{5}$ This policy shift had a transformative effect on the Indo-US relationship. In turn, it benefited from some key initiatives launched in the waning days of the Clinton administration. ${ }^{6}$ It is important to note that Bush expended an enormous amount of political capital to assist India. In particular, the administration set out to change domestic American laws in order to accommodate New Delhi. Additionally, Washington worked with friends and allies to alter international regimes in order to allow full civilian nuclear cooperation with India. ${ }^{7}$ From a strategic perspective the Bush administration made it clear that it wanted to assist India in joining the ranks of the great powers. As far back as the 2000 American presidential campaign, Condoleezza Rice argued that India had the potential to become a great power, and that the United States would do well to assist in this endeavour. It was also Rice who, in her position as Secretary of State in 2005, put forth a ground-breaking framework for cooperation with India. ${ }^{8}$ Consequently, when the Obama administration assumed office in January 2009, the Indo-US relationship was on an extraordinarily secure footing.

\section{Indo-US diplomacy during the Obama years}

Despite the significant progress that had been made in Indo-US relations during the 2000s, the Obama administration did not have an auspicious start with India in its first year in office. Almost at the outset the administration caused distress in New Delhi when its Special Representative for Afghanistan and Pakistan, the seasoned diplomat Richard Holbrooke, mentioned that he might include the Kashmir dispute in his portfolio. When rumours about this impending decision emerged from Washington, DC, it invoked a swift and belligerent response from New Delhi. Indian officials felt the new administration was not respecting Indian concerns on a core issue of sovereignty. Interestingly, India even hired lobbyists and used personal connections to keep Holbrooke from including India in his portfolio. ${ }^{9}$

It is crucial to note that upon taking office in 2009, President Obama confronted the worst financial crisis since the Great Depression and preventing the United States from collapsing into a second depression was of paramount importance to the White House. While relations with India were important, they simply did not garner the level of attention that the Bush administration had accorded to India. The lack of focus on India in the first six months of the new administration is illustrated by that fact that Secretary of State Hillary Clinton visited Japan, South Korea, Indonesia and China, but not India. ${ }^{10}$ Nicholas Burns, the American Under Secretary of State for Political Affairs from 2005 to 2008, describes a perception in 
India that New Delhi was not a priority in Washington. He points out that during Obama's first term the administration was preoccupied with the financial crisis, and its focus in foreign policy was directed at the wars in Iraq and Afghanistan, as well as preventing Iran from acquiring nuclear weapons. Even though strong ties with India were strategically important, India was not a major issue. With regard to India, Burns states, 'it was a classic Washington story of near term crisis crowding out long-term ambitions'. Indian officials privately complained to their American counterparts of the lack of attention Obama was paying to New Delhi. ${ }^{11}$ In fact, it would take eight months for the contours of Obama's India policy to emerge. ${ }^{12}$

The first breakthrough in Obama's first term came with Secretary Clinton's fourday trip to India in July 2009. This visit significantly eased concerns in India that the United States no longer viewed New Delhi as a major actor in global affairs. Clinton's trip was the longest ever for a Secretary of State to India. ${ }^{13}$ Most importantly, Clinton's trip set the stage for Indian Prime Minister Manmohan Singh's November 2009 visit to Washington.

Singh's visit was significant for multiple reasons. Crucially, by inviting the Indian Prime Minister to the White House for the first state visit of Obama's presidency, Obama was making clear to New Delhi that he attached great importance to bilateral relations, as well as Indian concerns over the threat of terrorism confronting India. ${ }^{14}$ Obama openly encouraged India to take a leadership role in Asia by stating, 'In Asia, Indian leadership is expanding prosperity and the security across the region. And the United States welcomes and encourages India's leadership role in helping to shape the rise of a stable, peaceful and prosperous Asia. ${ }^{15}$

Singh's trip to Washington was followed a year later with a visit by Obama to India. During this visit, Obama announced support for India to become a permanent member of the United Nations Security Council. ${ }^{16}$ Obama's support for India on the UNSC is best viewed through the lens of public diplomacy. While his remarks gave face to India and demonstrated to New Delhi that Washington was serious about building robust ties in multiple areas, the fact that China would veto another Asian permanent member on the UNSC made this a somewhat limited diplomatic gesture. In addition to calling for India to get a permanent seat, Obama stated that India was 'an indispensable partner' of the United States in the twentyfirst century. ${ }^{17}$ A more concrete gesture from Obama was in his announcement that the United States would help India obtain membership in four non-proliferation regimes, these being the Missile Technology Control Regime, the Wassenaar Group, the Australia Group and the Nuclear Suppliers Group. ${ }^{18}$

While there were frequent visits by top diplomats and heads of state on both sides during the period under review, two major events stand out. The first was the visit of Indian Prime Minister Narendra Modi to the United States in September 2014, and the second was President Obama's visit to India in January 2015. 


\section{Modi's trip to America}

Prior to becoming India's prime minister in the spring of 2014, Modi was banned from entering the United States. The US State Department had refused to issue him a visa by citing the International Religious Freedom Act, which banned foreign officials who were responsible for serious violations of religious freedom from entering the United States. In 2002, an anti-Muslim pogrom had taken place in the Indian state of Gujarat during Modi's term as the chief minister of the state. However, the American position began to change in late 2013 and early 2014 as it became increasingly likely that Modi would be India's next leader. In February 2014, the American government ended its visa ban on Modi and shortly thereafter he became India's prime minister in May. Importantly, Obama was determined to keep Indo-UN relations on stable ground, and personally contacted Modi on the phone after his election victory. ${ }^{19}$ While Modi's visa ban meant that he lacked strong ties with Washington, his September 2014 visit went exceedingly well. In New York, Modi sold out Madison Square Garden, he was greeted by thousands of members of the Indian diaspora, and in Washington with Obama, he renewed the 2005 Defense Cooperation Agreement for another ten years. This agreement stated that India and the United States would treat each other at the same level as their closest partners on issues of defence. ${ }^{20}$ The Obama-Modi summit surprised many observers in that the two leaders appeared to establish a form of personal rapport with each other. The summit also helped to allay fears in India that the United States was not a reliable partner and that it would be willing to provide vital spare parts to the defence sector in a time of conflict. ${ }^{21}$

Under Obama, the United States enjoyed a relatively high favourability rating with the Indian public, and perhaps more importantly a very low unfavourable rating. As can be seen in Figure 3.1, America's favourability ratings were roughly consistent with those of his predecessor, George W. Bush. Figure 3.2 shows that while unfavourable perceptions declined under Obama, there was a dip in favourable perceptions. In addition, in the years where data is available, Figure 3.3 shows that the Indian public had 'confidence in the US President'.

America's relatively high approval ratings in India, along with Obama's relationship with Modi, help explain why Obama was the chief guest at the sixty-sixth Republic Day on 26 January 2015. This was the first time an American president had this honour, and in making the journey, Obama was the first American president to visit India twice while in office. ${ }^{22}$ Obama attached so much importance to the visit to India that he even had to reschedule the annual State of the Union address. ${ }^{23} \mathrm{~A}$ joint statement issued by both Obama and Modi the day before the Republic Day event stated, 'A closer partnership with the United States and India is indispensable to promoting peace, prosperity and stability' Importantly, this statement mentioned not just the Indian Ocean region, but also the Asia Pacific, 


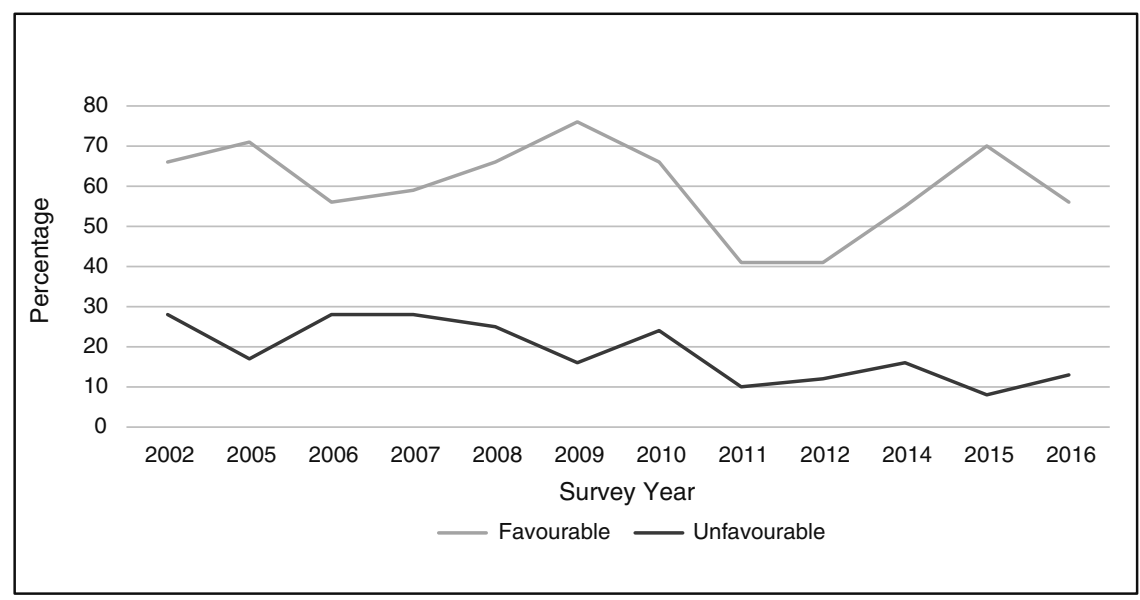

Note: Not shown are the "don't know" and "refuse" answer categories

3.1 Indian favourability ratings of the United States

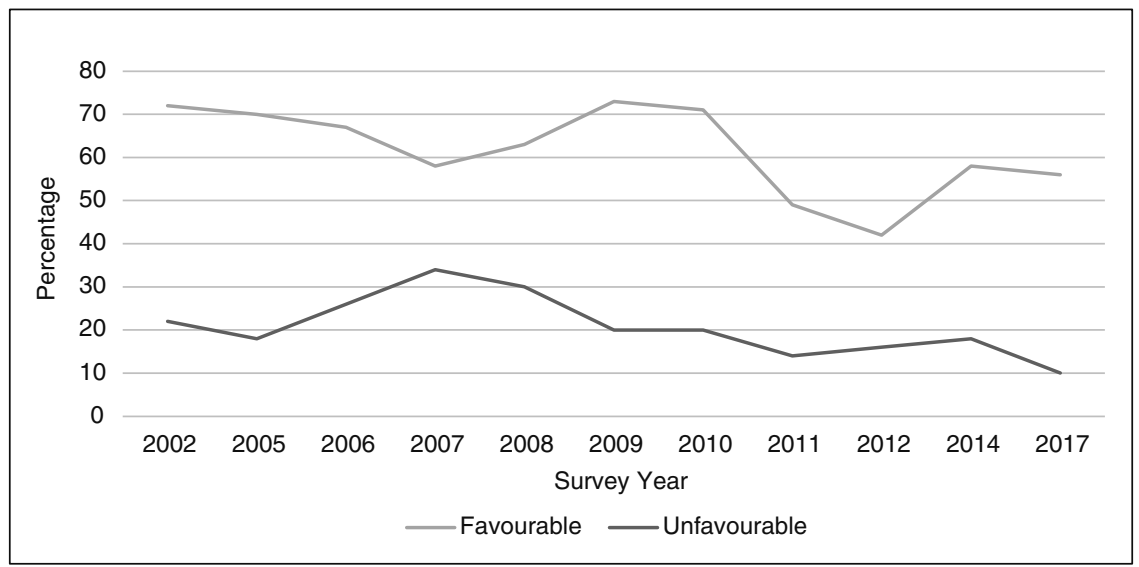

Note: Not shown are the "don't know" and "refuse" answer categories

\subsection{Indian favourability ratings of Americans}

thus clearly elevating India beyond the domain of a regional power. ${ }^{24}$ As will be discussed below, major progress was also made during this visit on a nuclear liability law that stood to benefit American companies. It needs to be noted that Modi's decision to invite Obama to the Republic Day parade constituted a costly signal in that it demonstrated that he was willing to stand up to the Indian left and the America-baiters within India's "attentive public". 


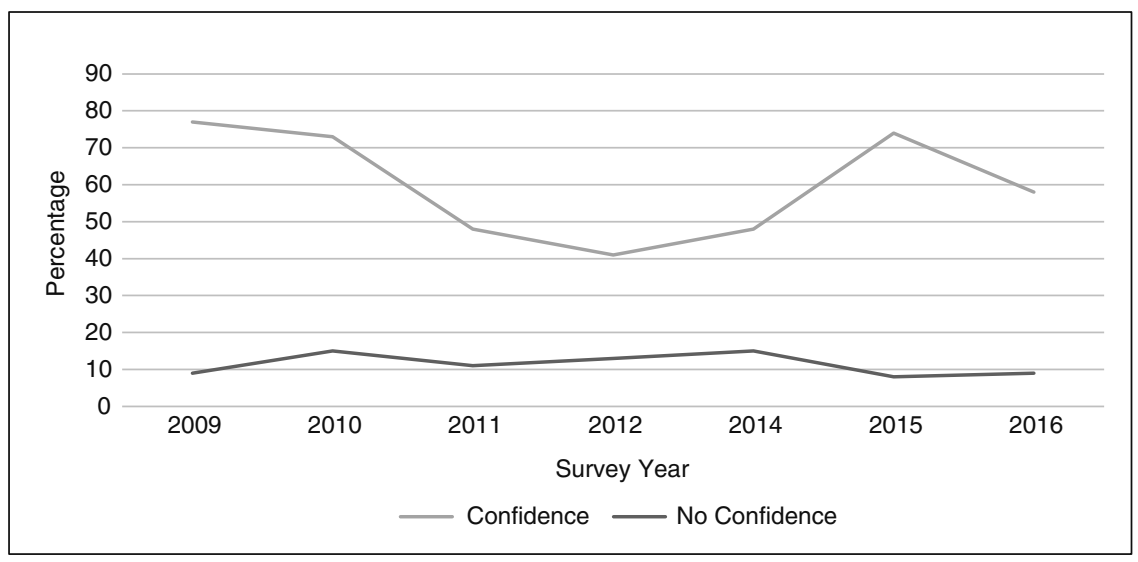

Note: Not shown are the "don't know" and "refuse" answer categories

3.3 Indian confidence in the American president

\section{Political and diplomatic challenges during the Obama era}

While Obama and Modi were able to reconcile their differences and come together in Obama's last two years in office, several political/diplomatic challenges showed that as Indo-US relations evolve and mature, significant hurdles remain. While not a major event, it is useful to briefly mention the arrest and strip search in New York of Devyani Khobragade, who was the Deputy Consul General for India, in New York. Mrs Khobragade was charged with visa fraud for bringing to the United States a domestic worker she planned to employ and for failing to pay the worker a minimum wage. The episode demonstrates that Indo-US relations during the Obama period were not strong enough to bypass such events. India retaliated to the arrest by downgrading security at the American Embassy in New Delhi (which could have had serious consequences) and by denying visas to American teachers employed at the American International School in New Delhi. ${ }^{25}$ This event also underscores Indian sensitivities towards real and perceived slights by the United States.

A much deeper political challenge is the fact that significant constituencies in India do not wish New Delhi to move towards a closer strategic partnership with the United States. From an ideational standpoint, closer ties to Washington could compromise India's room for political manoeuvre expressed in terms of its commitment to "strategic autonomy". The political left and the communist parties all harbour deep mistrust of the United States and American intentions. This fear of being seen as too close to Washington played a role in scuttling the multibillion dollar fighter-bomber deal with US defence contractors. ${ }^{26}$ At the national 
level, the Congress Party has concerns that it may lose support from the left, and Muslims, if it is perceived as being too close to America. Additionally, various defence related projects were held up for political reasons. For example, during a three-year period when A. K. Antony was India's Minister of Defence, the United States proposed seventeen defence-related projects, but did not receive a response from the Indian side. ${ }^{27}$

On the issue of diplomacy and foreign policy, the Obama administration had to contend with Indian strategic ties with Iran relating to its role in Afghanistan, and its fraught relationship with Pakistan. Afghanistan is a major concern to India and New Delhi sees it as a strategic rear base for Pakistan. India seeks to limit Pakistani influence in Afghanistan and to that end is the largest regional donor in Afghanistan with over US $\$ 2$ billion invested in reconstruction and development aid. New Delhi was not consulted or involved with American decision making in regard to pulling out of Afghanistan, which caused significant irritation in India. ${ }^{28}$ Washington and New Delhi do not always agree on how to deal with Iran. While a nuclear armed Iran is not in India's interest, Iran plays a significant role in India's energy imports, as well as being a transit point for goods to and from Central Asia. New Delhi is planning to build rail and road links from Afghanistan to the Iranian port of Chabahar to facilitate the flow of raw materials and goods from Afghanistan to India. In addition, India's large Shia Muslim population is a powerful constituency that promotes Indo-Iranian relations. These factors mean that New Delhi does not always endorse American sanctions on Iran. ${ }^{29}$

Overall, the Obama administration's public diplomacy towards India evolved over his two terms in office. While domestic factors and the wars in Iraq and Afghanistan kept India on the back burner in the first six months of his administration, by the end of 2009, relations with New Delhi were back on track. In terms of diplomacy, it is difficult to compare the Obama era with the previous Bush administration. Obama was constrained by the enormity of the financial crisis as well as the two wars he inherited from Bush. As ties between the two states started to mature, the economic links between the two increased, but not without challenges.

\section{Indo-US economic relations under Obama}

One of the reasons India was not taken seriously by the United States during much of the twentieth century was because of its anaemic economic record. In 2002, Robert Blackwell, then the American Ambassador to India, described the US trade flow to India as 'flat as chapatti. ${ }^{30}$ However, bilateral trade in goods picked up in the second term of the Bush administration, doubling from US $\$ 21$ billion in 2004, to US $\$ 43$ billion in 2008. ${ }^{31}$ By the end of Obama's second term, trade ties 


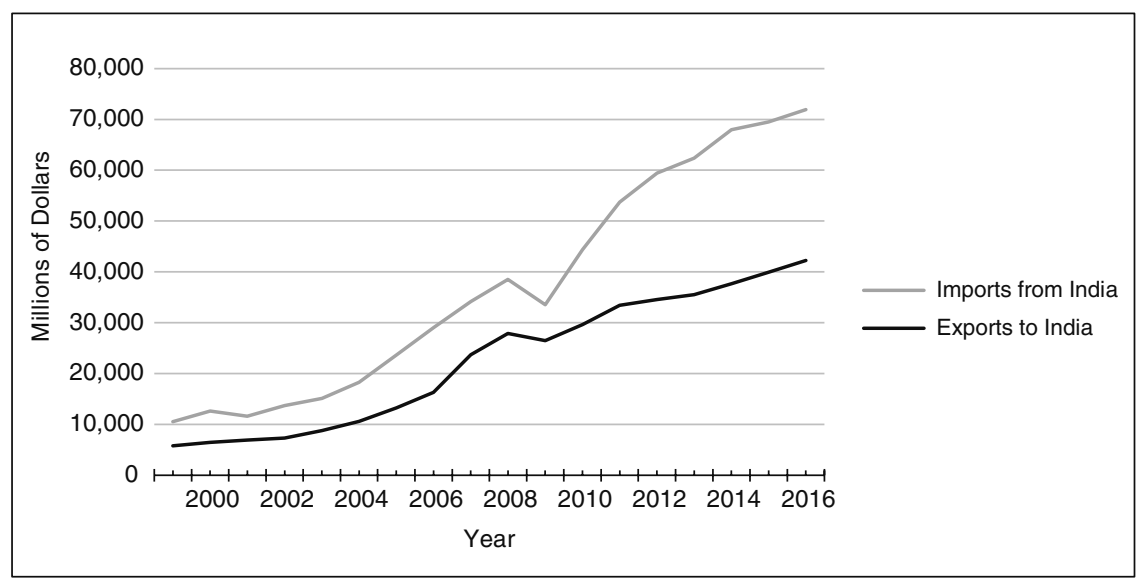

3.4 American trade with India under Bush and Obama

between the two states were rapidly expanding. As Figure 3.4 demonstrates, trade increased by over 600 per cent from 2000-17.

\section{Opportunities for Indo-US bilateral trade}

On the surface, the United States and India should have relatively complementary economic ties. India's former Ambassador to the UN, Jaskaran Teja, argues that at the centre of Modi's diplomacy is the need for high technology and capital resources from Western countries, but primarily from the United States. ${ }^{32}$ India has an abundance of cheap labour and if it is able to push further economic liberalisation, could become a major source of manufacturing for Western markets. As Tellis and Mohan argue, India must understand that long-term economic growth is based on increasing global trade links, and increasing ties with the United States will enhance this. ${ }^{33}$ The United States has also become a major trading partner for India over the past fifteen years. In 2001, India was America's twenty-fifth largest trading partner and by 2014 it had risen to eleventh. While America was India's second largest source of foreign direct investment (FDI) in 2001, it fell to fifth largest in 2014. The overall increase was from 370 million in 2001, to 1.7 billion in $2014 .{ }^{34}$ Crucially, when all goods and services are taken into account, the United States is India's largest trading partner. ${ }^{35}$

Links in the form of FDI with the United States have expanded dramatically since 2000. As Figure 3.5 shows, with the exception of the period surrounding the global financial crisis, bilateral FDI steadily increased over the past two American administrations. 


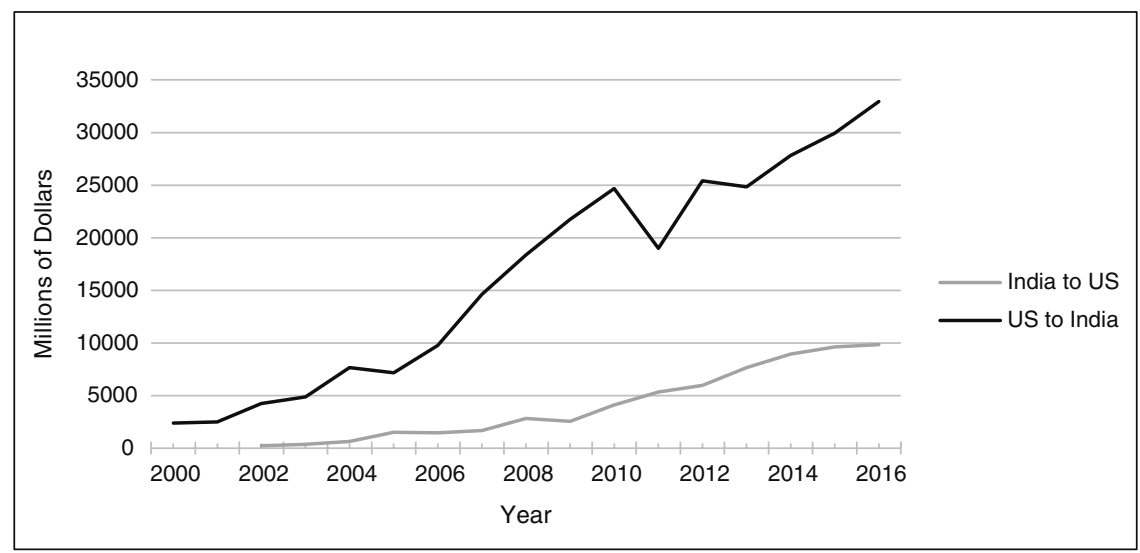

3.5 Bilateral Indo-US FDI

\section{Challenges to Indo-US bilateral trade}

While the data shows increasing economic ties between the United States and India, under the Obama administration there was still limited economic interdependence. ${ }^{36}$ One of the greatest obstacles to further economic integration during the Obama era stemmed from Indian domestic politics. The difficulties associated with the landmark nuclear deal exemplify this problem. After it was signed in 2008, a nuclear liability law in 2010 made it nearly impossible for American firms to benefit from the deal. Specifically, the new law did not cap liability exposure for nuclear suppliers, thus discouraging private American firms from taking part in a deal established by their own government. ${ }^{37}$ Importantly, the legislation was passed in August 2010 just as Indian courts were releasing their final judgments on the horrific Bhopal incident where, in 1984, a chemical leak killed up to 16,000 Indians in the country's worst ever industrial accident. ${ }^{38}$ While the courts' concern for the impact that such industries may have on local populations is justified, it has a severe impact on foreign perceptions of doing business and investing in India. What should have been a cornerstone and shining example of Indo-US economic ties, turned out to be a warning and deterrent to American investors in India. ${ }^{39}$

As the Indian economy slowed in 2012-13, New Delhi started to impose discriminatory taxes on foreign investors and began to erect protectionist measures. Trade disputes followed with American firms complaining about Indian protectionism, and both countries filing suits in the World Trade Organization (WTO). The United States banned imports of more than a dozen Indian plants used by the pharmaceutical industry. ${ }^{40}$ One basic measure that compares the comparative openness of the US and Indian markets is in the simple average bound tariff. At 
the start of Obama's second term the tariff for all products in the United States was 3.5 per cent, while in India it was 48.6 per cent. When this is compared to the average GDP per capita in each country, with the United States at US $\$ 53,000$ and India at US\$1,500, the lure of the Indian market is greatly diminished for American firms. New Delhi resists opening the India market because of the political costs and the inability of Indian firms to compete with more efficient American ones. ${ }^{41}$

Under Obama, American firms also frequently complained about violations of intellectual property rights (IPR) by Indian firms. Specifically, the Office of the United States Trade Representative placed India on its priority watch list and scheduled an Out-of-Cycle-Review (OCR) in the autumn of 2014 to look into this issue. Creating an OCR was an escalation because it can lead to recommended sanctions based on the trade representative's report. Realizing the negative impact of such a report, the September 2014 Summit between Obama and Modi addressed issues such as IPR and set up a working group to deal with this issue. In addition, the Indian Ministry of Commerce established a thinktank that focuses on IPR issues. ${ }^{42}$ The full impact of these measures has yet to be seen, but it is necessary to note that New Delhi is at least cognizant of American concerns over IPR.

Overall, economic ties between India and the United States increased substantially during the Obama era. Talk of reaching US $\$ 500$ billion a year in total trade may be premature, but if Washington and New Delhi are able to work out some difficult challenges on a potential free trade agreement, it is possible that bilateral trade would explode. However, there are also severe roadblocks to sustained increases in trade. Domestic Indian political calculations may well tie Modis or his successor's hands. In addition, some of the structural deficiencies of the Indian economy, such as poor infrastructure and a small middle class, may prevent deeper economic ties. ${ }^{43}$ While the structure of the Indian political system and economy may hinder deeper economic ties, the changing dynamics of the international system is driving them closer together.

\section{Indo-US security ties during the Obama era}

While America's political and economic ties experienced challenges under Obama, security relations between the two were robust and even strengthened during his eight years in office. This section argues that the best explanation for Washington's strategic embrace of New Delhi is found in an attempt to hedge against a rising China. Both the United States and India are involved in strategic rivalries with China $^{44}$ and, over the past decade and a half, these two separate rivalries are increasingly linked together. The expanding assertiveness of the Chinese People's 
Liberation Army and Navy (PLA and PLAN), as well as China's overall growing power, is causing states all over Asia to rethink their security strategies vis-à-vis China. ${ }^{45}$

The rise of China provides Washington and New Delhi with both opportunities and strategic threats. The opportunities lie in the potential economic benefits that working and trading with China can deliver. The threats stem from the strategic rivalry that China poses to both the United States and India. For the United States, working with India in the security realm helps to preserve American hegemony while also assisting India in its rivalry with China. While both states are engaged in hedging, they are not aiming to "contain" China. A strategy of containment requires a state to prevent another state's rise by attempting to exclude it from the international community, while also working against it in multiple arenas. ${ }^{46}$ Hedging, according to Tunsjo, is:

The development and implementation of government strategies aimed at reconciling conciliation and confrontation in order to remain reasonably wellpositioned regardless of future developments ... States hedge by combining contradictory cooperative and confrontational strategies to produce a balanced approach in order to manage uncertainty. ${ }^{47}$

India is both actively working with China in the economic realm, while also preparing for a worst-case security scenario. Figure 3.6 shows the expanding economic ties between India and China, demonstrating the absence of a clear containment policy.

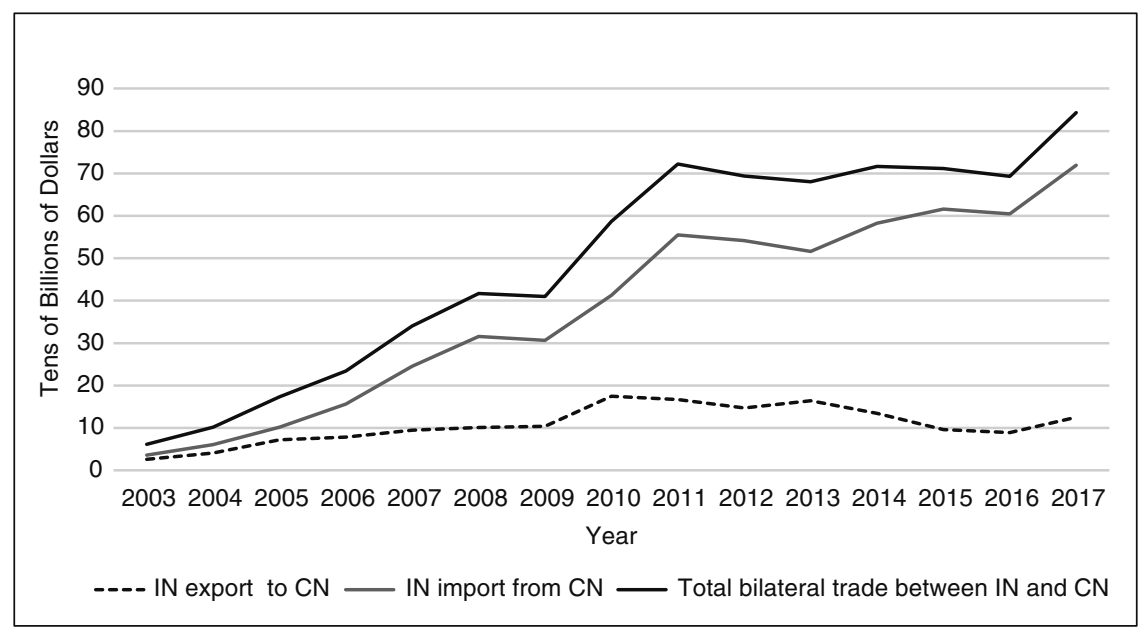

3.6 Sino-Indian bilateral trade 


\section{Rivalry dynamics}

Indian leaders have harboured deep suspicions about China dating back to the foundations of both states in the late 1940s. ${ }^{48}$ The 1962 war between India and China, where mechanised PLA forces quickly defeated the ill-equipped Indian army, had a traumatic impact on leaders in New Delhi. As the Chinese military has recently increased its power and, more importantly, its ability to project power into the Indian Ocean Region (IOR), threat perceptions in India have increased dramatically. The rise of China has the potential to radically alter the geopolitical strategic landscape in ways that may be detrimental to American and India interests. Given these circumstances, it is understandable that Washington and New Delhi work together to deal with a much more powerful and increasingly assertive China. As Paul Kapur argues, India's policies towards the United States and China are interconnected, and it is 'impossible to understand the Indian position on one without understanding its position on the other. ${ }^{4} 9$

Obama's Pivot to Asia was a way to shift America's strategic focus to the Asia Pacific region. Behind this was a critical aspect that encouraged American partners and allies to work together to balance the rise of China. A key component of this was to increase military interoperability amongst America and its allies. ${ }^{50}$ For American strategists India was an important component of the Pivot. American Secretary of Defense Leon Panetta specifically referred to India as the 'linchpin' of this strategy, ${ }^{51}$ while Secretary of State John Kerry spoke of India as playing a critical role. ${ }^{52}$

\section{Arms sales}

Between 2009 and 2017, the Obama administration played a key role in providing the Indian military with advanced weapons systems. High profile purchases included C-130JS Super Hercules and ten C-17 transport planes; twenty-four Harpoon Block II missiles; eight P-8Is (vital for anti-submarine warfare); as well as Apache helicopter gunships. In addition, the Pentagon helped the Indian military in ways less visible such as sharing information about key choke points in the IOR where PLAN submarines are likely to transit, working with the Indian navy on undersea sensors, and assisting in the construction of catapults on India's new aircraft carriers. ${ }^{53}$ While the United States is not India's largest source of foreign military hardware, as Figure 3.7 demonstrates, during the Obama administration American arms exports to India increased dramatically.

By collaborating with the United States in the security realm, India is able to gain access to not only American technology and know-how, but improve its tactics in military exercises such as Malabar, Salex and RIMPAC (Rim of the Pacific Exercise). (India was an observer to RIMPAC from 2004-10, but 


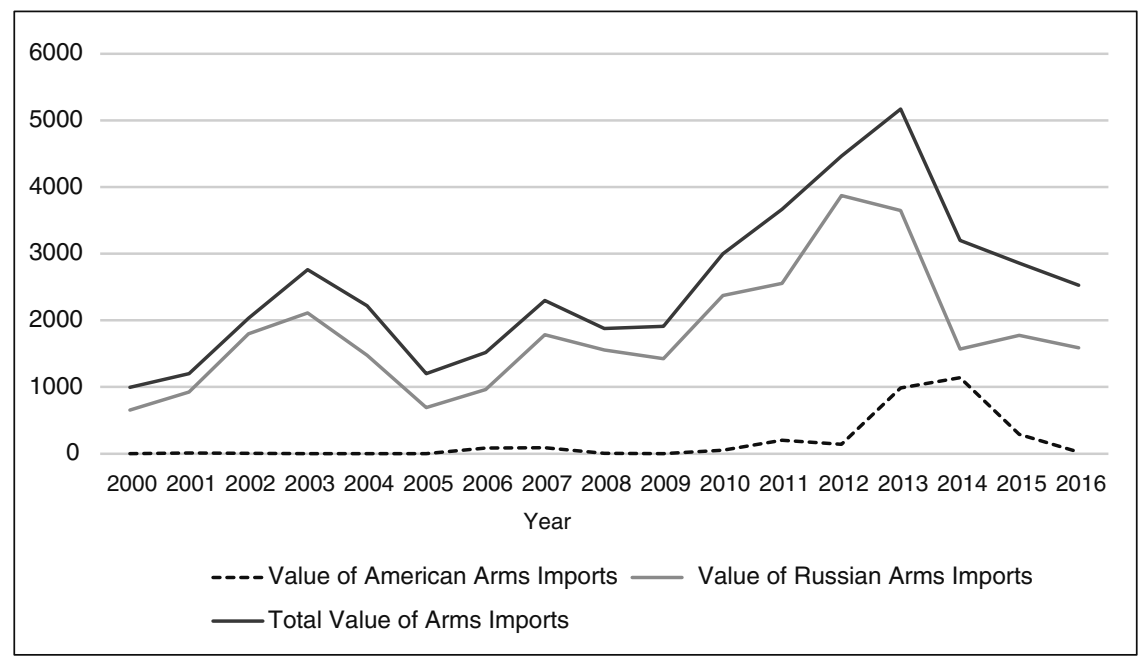

3.7 Indian arms imports in SIPRI's trend indicator values

a participant from 2012.) ${ }^{54}$ The Chinese are acutely aware of the strengthening security ties between the United States and India but seem tone deaf to India's concerns of Chinese encirclement. A prime example of this was Xi Jinping's state visit to India in September 2014 during which Chinese forces crossed the Line of Actual Control that separates India and Chinese controlled territory in Tibet. The manoeuvre was viewed as a major insult to Prime Minister Modi and left Indians speculating why the crossing was ordered. ${ }^{55}$ This episode along with the Chinese Belt and Road Initiative (BRI), through which hundreds of billions of dollars will be invested in hard infrastructure in the region, increases Indian fears of Chinese encirclement. The BRI's China Pakistan Economic Corridor crosses through disputed territory in Pakistani controlled Kashmir. China did not consult India about this massive project and because New Delhi sees it as a violation of Indian sovereignty in Kashmir, it has boycotted the initiative.

\section{Change or continuity under Trump?}

The Obama administration remitted office with Indo-US relations on a mostly even keel. President Trump, during his election campaign, had only focused on India when dealing with the issue of the apparently questionable allotment of $\mathrm{H1}$ $\mathrm{B}$ visas which permit foreign professionals to work for specified periods in the United States. Upon assuming office, in the context of unfair trade practices, he 
mentioned India on a few occasions. His anti-immigrant remarks, though not specifically directed against those of Indian origin, have nevertheless caused some concern in New Delhi.

On the issue of trade, as of early 2019, the Trump administration is considering withdrawing the privileges India was granted under the Generalized System of Privileges. Through this agreement India has been able to export billions of dollars of goods to the United States tax free. The Trump administration's action follows a surprise move by New Delhi in December 2018 that made it more difficult for the American firms Amazon and Walmart to conduct e-commerce in India. India took action out of concern that Indian firms will not be able to compete with the two American companies. ${ }^{56}$

That said, in other areas, most notably regional security, the Trump administration has, for the most part, maintained the policies of his predecessor. To that end, in September 2018 he sent former Secretary of Defense, James Mattis, to India. During his visit Mattis made clear that the administration saw India as a bulwark for regional stability and that the United States was willing to continue weapons sales to India. Also, much to the delight of New Delhi, in early 2018 Trump announced that he was suspending over $\$ 2$ billion worth of aid to Pakistan, India's nettlesome neighbour, because of its failure to rein in support for terror. In addition, the announcement in mid-2018 of the name change of the US Pacific Command (PACOM) to the US Indo-Pacific Command is an important piece of diplomacy. Even though PACOM had jurisdiction over India since the end of the Second World War, the symbolic renaming demonstrated to New Delhi that India matters in American geostrategic calculations. ${ }^{57}$

Given the Trump administration's significant misgivings about China on a variety of fronts, as of early 2019, it seems reasonable to conclude that it will continue with the trajectory laid out by the George W. Bush and Obama administrations and seek to engage India in an attempt to balance against China. Of course, the scope and dimensions of this engagement to some degree also depend on India's willingness to work with the United States. As argued earlier in this chapter, elements within India's political establishment still remain wary of the prospect of an overly robust strategic partnership with the United States. Unless a significant shift takes place within India's political culture despite the progress that has been made in the recent past, there may be distinct limits to the Indo-US strategic partnership.

\section{Conclusion}

Indo-US relations during the Obama era had a fitful start. On the domestic front, the financial crisis was a clear and present danger that the White House had to deal with immediately. In terms of foreign policy, the wars in Iraq and Afghanistan took priority in the first six months of the new administration. However, Hillary 
Clinton's July 2009 trip to India and Prime Minister Singh's trip to Washington in November of that year placed the relationship back on track. As bilateral ties increased, challenges that could be ignored, or did not exist during the Bush years, began to demand attention. Concerns over IPR and market accessibility became major impediments in the relationship. These were partially offset by the personal ties between Obama and his Indian counterparts. While economic ties between the United States and India increased dramatically during Obama's two terms, the full potential of economic ties were blocked by both political factors in India and by the structural deficiencies of the Indian economy.

While political and economic ties may not be as robust as they could be, the foundation of the relationship is centred on security ties. Faced with a rising China that exhibits increasingly assertive behaviour, and that is locked in a strategic rivalry with both India and the United States, New Delhi and Washington have found common cause to work together. This is unlikely to change dramatically during the remainder of the Trump administration unless trade and immigration issues really come to the fore and cause the relationship to flounder. Furthermore, as argued earlier in this chapter, significant political constituencies are against a form of direct external balancing and it is not clear how eager India is to join the United States in a strategic alignment specifically designed to confront China. ${ }^{58}$ This situation could change in the near future as China continues to make major inroads into the IOR and on India's northern periphery. These developments may induce those within India's political establishment who remain leery about a closer alignment with the United States to reconsider their stance.

\section{Notes}

1 A. Tellis, 'US India relations: The struggle for an enduring partnership', in D. M. Malone, C. R. Mohan and S. Raghavan (eds.), The Oxford Handbook of Indian Foreign Policy (Oxford: Oxford University Press, 2015), p. 484.

2 Ibid., p. 486.

3 P. S. Kapur, 'India and the United States from World War II to the present: A relationship transformed', in S. Ganguly (ed.), India's Foreign Policy (Oxford: Oxford University Press, 2009), pp. 251-74.

4 Ibid., p. 259.

5 S. Ganguly and D. Mistry, 'The case for the US-India nuclear agreement', World Policy Journal, 23:2 (2006), pp. 11-19.

6 S. Talbott, Engaging India: Democracy, Diplomacy and the Bomb (Washington, DC: Brookings Institution Press, 2004).

7 H. Pant, India and the United States: An Emerging Partnership (Manchester: Manchester University Press, 2016), p. 23. 
$8 \quad$ Ibid., pp. 24-5.

9 J. Kirk, 'India's season of discontent: US-India relations through the prism of Obama's “Af-Pak” policy, year one', Asian Affairs, 37:3 (2010), p. 153.

10 Ibid.

11 N. Burns, 'Passage to India', Foreign Affairs, 93:5 (2014), p. 134.

12 R. Kumar, 'New potential for US-India relations under Obama', The International Spectator, 44:4 (2009), p. 21.

13 C. Mahapatra, 'Obama administration II and India', Indian Foreign Affairs Journal, 8:2 (2013), p. 196.

14 Kirk, 'India's season of discontent', p. 148.

15 White House, 'Remarks by President Obama and Prime Minister Singh of India in Joint Press Conference’ (24 November 2009), https://obamawhitehouse.archives. gov/the-press-office/remarks-president-obama-and-prime-minister-singh-indiajoint-press-conference, accessed 9 March 2019.

16 V. Samson, 'India, China, and the United States in space: Partners, competitors, combatants? A perspective from the United States', India Review, 10:4 (2011), p. 429.

17 Mahapatra, 'Obama administration II and India', p. 194.

18 Ibid., p. 431.

19 H. Pant, 'Modi's unexpected boost to India-U.S. relations', The Washington Quarterly, 37:3 (2014), pp. 93-6.

20 Ibid., p. 107.

21 J. Teja, 'The new India-US reset', American Foreign Policy Interests, 36:6 (2014), p. 382.

22 Brookings India Center, 'The Second Modi-Obama Summit: Building the India-US Partnership', The Brookings Institution (January 2015), www.brookings.edu/wpcontent/uploads/2016/06/The-Second-Modi-Obama-Summit-Briefing-Book.pdf, 9 March 2019.

23 A. Tellis and C. R. Mohan, 'The Strategic Rationale for Deeper US-Indian Economic Ties: American and Indian Perspectives', Carnegie Endowment for International Peace (2015), http://carnegieendowment.org/files/US_India_ TellisMohan_Final.pdf, p. 73, accessed 9 March 2019.

24 White House, 'US-India Joint Strategic Vision for the Asia-Pacific and the Indian Ocean Region' (25 January 2015), https://obamawhitehouse.archives.gov/thepress-office/2015/01/25/us-india-joint-strategic-vision-asia-pacific-and-indianocean-region, accessed 9 March 2019.

25 Burns, 'Passage to India', p. 126.

26 S. Ganguly and W. Thompson, Ascending India and its State Capacity (New Haven: Yale University Press, 2017), p. 248 and p. 260.

27 A. Vasudeva, 'US-India Defense Ties: A Delicate Dance', Foreign Policy (8 October 2015), http://foreignpolicy.com/2015/10/08/u-s-india-defense-ties-a-delicatedance/, accessed 9 March 2019.

28 J. D. Schmidt, 'The Asia-Pacific strategic triangle: Unentangling the India, China, US relations on conflict and security in South Asia, Journal of Asian Security and International Affairs, 1:2 (2014), p. 214. 
29 Ibid., pp. 215-16.

30 E. A. Feigenbaum, 'India's rise, America's interest: The fate of the US-Indian partnership', Foreign Affairs, 8:2 (2010), p. 78.

31 US Census Bureau, 'Trade in Goods with India' (2018), www.census.gov/foreigntrade/balance/c5330.html, accessed 10 March 2019.

32 J. Teja, 'The new India-US reset', American Foreign Policy Interests, 36:6 (2014), p. 376.

33 Tellis and Mohan, 'The Strategic Rationale', p. 16.

34 Ibid., p. 34.

35 Ibid., p. 73.

36 Ibid., p. 1.

37 Pant, 'Modi's unexpected boost', p. 98.

38 T. C. Schaffer and H. B. Schaffer, India at the Global High Table: The Quest for Regional Primacy and Strategic Autonomy (Washington, DC: Brookings Institution Press, 2016), p. 178.

39 Burns, 'Passage to India', p. 134.

40 Ibid., p. 137.

41 Tellis and Mohan, 'The Strategic Rationale', pp. 32-3.

42 Brookings India Center, 'The Second Modi-Obama Summit', p. 27.

43 See Ganguly and Thompson, Ascending India and its State Capacity, ch. 6.

44 M. Colaresi, K. Rasler and W. Thompson, Strategic Rivalries in World Politics (Cambridge: Cambridge University Press, 2007).

45 A. Liff, 'Wither the balancers? The case for a methodological reset', Security Studies, 25:3 (2016), pp. 420-59; R. S. Ross and O. Tunsjø (eds.), Strategic Adjustment and the Rise of China (Ithaca: Cornell University Press, 2017).

46 G. Kennan, 'The sources of Soviet conduct', Foreign Affairs, 25:4 (1947), pp. 566-82.

47 O. Tunsjø, 'US-China relations: From unipolar hedging toward bipolar balancing, in Ross and Tunsjø, Strategic Adjustment, p. 46.

48 J. Garver, Protracted Contest: Sino-Indian Rivalry in the Twentieth Century (Seattle: University of Washington Press, 2003).

49 P. Kapur, 'India's relationship with the United States and China', in T. Fingar (ed.), The New Great Game: China and South and Central Asia in the Era of Reform (Stanford: Stanford University Press, 2016), p. 54.

50 N. Silove, 'The Pivot before the Pivot: US strategy to preserve the power balance in Asia', International Security, 40:4 (2016), pp. 45-88.

51 S. Hu, 'India's rise and China's response', in Fingar, The New Great Game, p. 79.

52 Mahapatra, 'Obama administration II and India', p. 200.

53 Interviews conducted by Christopher K. Colley with India defence experts, New Delhi, India (Summer 2016).

54 D. Scott, "The "India-Pacific": New regional formulations and new maritime frameworks for US-India strategic convergence', Asia-Pacific Review, 19:2 (2012), p. 99.

55 Interviews conducted by Christopher K. Colley with Indian security experts, New Delhi, India (Summer 2016). 
56 J. Slater, 'Is India the Next Target in the Trump Administration's Trade Wars?', The Washington Post (13 February 2019), www.washingtonpost.com/world/ asia_pacific/is-india-the-next-target-in-the-trump-administrations-tradewars/2019/02/13/d1d7d896-2f90-11e9-ac6c-14eea99d5e24_story.html?utm_ term $=.322 \mathrm{~d} 5 \mathrm{cf} 8 \mathrm{c} 9 \mathrm{~b} 0$, accessed 10 March 2019.

57 K. Parpiani, 'India-US Relations Under Trump: Guarding Against Transactionalism by Pivoting to the US Legislature', ORF Issue Brief no. 262 (October 2018), www.orfonline.org/research/india-us-relations-under-trumpguarding-against-transactionalism-by-pivoting-to-the-us-legislature-45058/, accessed 10 March 2019.

58 Ganguly and Thompson, Ascending India and its State Capacity, p. 261. 